\title{
PENGUATAN KAPASITAS MARKETING PRODUK INDUSTRI KREATIF BERBASIS MARKETING SYARIAH DAN PEMANFAATAN IT DI SLEMAN
}

\author{
Nur Kholis ${ }^{1^{*}}$, Unggul Priyadi ${ }^{2}$, Hendrik ${ }^{3}$ \\ ${ }^{1}$ Prodi Ekonomi Islam UII \\ ${ }^{2}$ Prodi Ilmu Ekonomi FE UII \\ ${ }^{3}$ Prodi Informatika FTI UII \\ *014210101@uii.ac.id, nurkholisyes@gmail.com
}

\section{ABSTRACT}

Daerah Istimewa Yogyakarta province has a strategic position in developing creative industries. One of the districts that support these creative industries is Sleman. However, SMEs in Sleman district still largely prosperous, because they do not take more advantage of IT development to increase sales. The problems of this study, how to construct the marketingmodel for product of creative industries that adopted the principles of sharia marketing by utilizing the E-Commerce portal to increase revenues and competitiveness of creative industries in Sleman at the level of domestic market and international market. This research has produced an e-commerce portal (http://jogjakreatif. com) equipped with SMS gateway that enables traders of creative industries in Sleman to promote and conduct transactions with customers on line-based or sms. Through this facility, traders are not required to check transaction activity every time, but they can obtain latest information regarding transactions via email and sms.

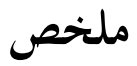

محافظةيوكياكرتا الخاصة لديها موقع استراتيجي في تطوير الصناعات الإبداعية. واحدة من المناطق التي تدعم هذه الصناعات الإبداعية هو منطقة سليمان. ومع ذلك، الشركات الصغيرة والمتوسطة في منطقة سليمان لا تزال مزدهرا إلى حد كبير، لأهفا لا تأحذ أكثر فائدة من تطوير تكنولوجيا المعلومات لزيادة المبيعات. مشاكل هذه الدراسة هي كيفية بناء نموذج التسويق لمنتج الصناعات الإبداعية التي اعتمدت مبادئ 
التسويق الشرعية من خلال الاستفادة لبوابة التجارة الإلكترونية لزيادة الإيرادات والقدرة التنافسية للصناعات الإبداعية فيمنطقة سليمان على مستوى الأسواق المحلية

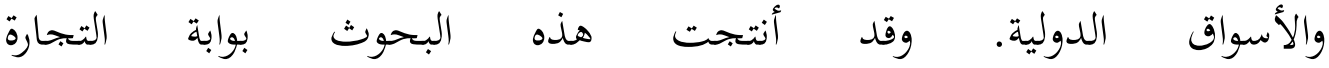
الإلكترونية(http:/jogjakreatif.com) بحهزة ببوابة الرسائل القصيرة التي تمكن تجار الصناعات الإبداعية فيمنطقة سليمان إلى تعزيز وإجراء المعاملات مع العمالاء على أساس خط أو الرسائل القصيرة. من خلال هذه الخدمة، لا يحتاج التجار إلى التأكد من نشاط المعاملات في كل مرة، ولكن يمكنهم الحصول على أحدث المعلومات المتعلقة بالمعاملات عبر البريد الإلكتروين والرسائل القصيرة.

Keywords: industri kreatif, model penguatan kapasitas marketing, Syariah Marketing Index (SMI), portal e-commerce, pemanfaatan IT

\section{A. Pendahuluan}

Usaha mengembangkan ekonomi kreatif yang dilakukan pemerintah secara melembaga diawali sejak ditetapkannya Inpres Nomor 6 Tahun 2009 tentang Pengembangan Ekonomi Kreatif. Pelaksanaan Inpres tersebut sebagai upaya mendukung kebijakan Pengembangan Ekonomi Kreatif Nasional Tahun 20092015 yakni pengembangan kegiatan ekonomi berdasarkan pada kreativitas, ketrampilan dan bakat individu untuk menciptakan daya kreasi dan daya cipta individu yang bernilai ekonomis dan berpengaruh pada kesejahteraan masyarakat dengan sasaran, arah dan strategi tertentu. ${ }^{1}$ Dalam pengembangan ekonomi kreatif mencakup 14 sektor dan sektor kuliner yang sedang diperjuangkan Kementerian Pariwisata dan Industri Kreatif menjadi salah satu sektor industri kreatif.

Propinsi Daerah Istimewa Yogyakarta (DIY) mempunyai posisi strategis dalam upaya mengembangkan industri kreatif. Hal ini berkaitan berbagai

1 Khusus untuk di D.I. Yogyakarta, master plan pengembangannya dapat dibaca dalam hasil riset yang ditulis Unggul Priyadi (2011) Penyusunan Master Plan Pengembangan Ekonomi Kreatif di Propinsi DIY Tahun 2011, Didanai BAPPEDA DIY 
predikat yang melekat, seperti, daerah tujuan wisata ke dua setelah Bali, Kota Budaya, Kota Pendidikan, banyaknya makanan kuliner khas Yogya, banyaknya UMKM. Salah satu kabupaten yang mendukung kekhasan Propinsi DIY salah satunya adalah Kabupaten Sleman. Suatu keadaan yang tidak menguntungkan secara ekonomi, walaupun wilayah tersebut sebagai pendukung kekhasan Propinsi DIY kehidupan masyarakat di Kabupaten Sleman masih belum sejahtera. Jumlah warga miskin di Kabupaten Sleman sebanyak 173.152 jiwa. ${ }^{2}$

Salah satu penyebab terjadinya hal tersebut adalah banyak pelaku UMKM sebagai bagian integral pelaku industri kreatif belum memanfaatkan kemajuan teknologi informasi (IT) untuk meningkatkan penjualan secara optimal. Salah satu hasil riset yang dilakukan oleh Wahid \& Iswari terhadap 146 UMKM yang ada di Yogyakarta pada berbagai sektor industri, ditemukan bahwa adopsi Teknologi Informasi oleh UMKM masih rendah. Umumnya, pelaku UMKM tersebut memanfaatkan internet untuk mencari informasi pasar $(48,9 \%)$ dan desain $(42,7 \%)$. Sedangkan aktivitas pemasaran secara online berada di posisi ketiga sebesar 32,3\%. Namun untuk transaksi secara online baru mencapai 15,6 persen. ${ }^{3}$

Rata-rata dari sisi design produk, tingkat produktivitas, kualitas produk industri kreatif cukup bersaing. Permasalahan utama yang dihadapai oleh pelaku industri kreatif adalah pemasaran kepada segmen dan target yang lebih luas. Salah satu hasil riset yang dilakukan oleh DPPM UII menyatakan bahwa masalah utama yang dihadapai oleh industri kreatif (di antaranya pengrajin bambu) adalah masalah pemasaran. Hal ini disebabkan antara lain rendahnya tingkat penguasaan teknologi yang menyebabkan produknya tidak dapat bersaing dengan produk luar negeri. ${ }^{4}$

Berkaitan dengan hal tersebut, dalam upaya meningkatkan pendapatan dan daya saing pelaku industri kreatif perlu dilakukan upaya komprehensif.

2 Gubernur DIY, 2006" Pelaksanaan Layanan Kesehatan Bagi Masyarakat Miskin Di DIY dalam Seminar Nasional Pelayanan Kesehatan Keluarga Miskin (Gakin) Antara Harapan dan Kenyataan dalam http://www.pemda-diy.go.id/berita/article.php?op=Print\&sid=2337 diakses pada tanggal 16 Agustus 2014

3 Wahid, F., \& Iswari, L. (2007). Adopsi Teknologi Informasi Oleh Usaha Kecil dan Mengengah di Indonesia. Seminar Nasional Aplikasi Teknologi Informasi (SNATI) 2007 (Vol. 2007), hal. 76.

4 TIM PPST-DPPM UII (2007), Studi Potensi Bambu Dusun Brajan, Hasil Penelitian, Yogyakarta: DPPM UII. 
Salah satu alternatif dalam meningkatkan pemasaran adalah dengan pendekatan pemasaran yang berbasis pada IT yang berbentuk Portal E-commerce dengan mendasarkan pemasaran yang menegakan prinsip-prinsip syariah. ${ }^{5} \mathrm{Un}$ tuk itu diperlukan penguatan kapasitas internal pelaku industri kreatif dengan pemahaman pada pemasaran syariah yang diukur dengan Syariah Marketing Index (SMI) dan exposure produk dengan pemanfaatan portal e-commerce ${ }^{6}$ de-ngan menerapkan Syariah Marketing Index (SMI) yang berorientasikan pada Sustainable Marketing Enterprise (SME). ${ }^{7}$

Permasalahan penelitian ini adalah bagaimana model penguatan kapasitas pemasaran produk industri kreatif yang menggunakan prinsip pemasaran syariah dengan memanfaatkan portal E-Commerce Syariah dalam rangka meningkatkan pendapatan dan daya saing produk industri kreatif di Kabupaten Sleman di tingkat pasar domestik dan pasar internasional.

Manfaat penelitian ini adalah:

a. Semakin meluasnya (bahkan go international) jangkauan marketing produk industri kreatif yang dihasilkan dari Kabupaten Sleman. ${ }^{8}$

b. Semakin mudah dan murahnya transaksi untuk produk industri kreatif yang dihasilkan sehingga berdampak pada semakin competitivenya produk tersebut di pasaran.

c. Semakin mengakrabkan masyarakat dengan kemajuan teknologi IT, sehingga mendorong mereka untuk memanfaatkan kemajuan IT tersebut

5 Hermawan Kertajaya \& M. Syakir Sula (2006), Syariah Marketing. Bandung: Mizan dan MarkPlus\&Co. Bagaimana Rasulullah mempraktikkan bisnis dapat dibaca lebih lanjut dalam Afzalurrahman, 1997, Muhammad Sebagai Seorang Pedagang, Jakarta: Yayasan Swarma Bhuny.

6 Andam, Z. R. (2003). e-Commerce and e-Business (pp. 1-47). Kuala Lumpur. Lihat juga Lai, S.-ling. (2010). Social Commerce - E-Commerce in Social Media Context. World Academy of Science, Engineering and Technology 722010 (pp. 39-44); OECD. (2004). ICT, E-BUSINESS AND SMEs. Paris; UN-ESCWA. (2010). Social Media, e-Commerce and NGOs.

7 Sustainable Marketing Enterprise (SME) dapat dibaca lebih lanjut dalam Hermawan Kertajaya (2002), MarkPlus On Strategy. Jakarta: PT Gramedia Pustaka Utama dan Philip Kotler (1997), Marketing Management, $9^{\text {th }}$ edition. Prentice Hall Publishing. Betapa pentingnya kejujuran dalam marketing, dapat ditelusur lebih lanjut pada Stephen R. Covey (2004), The $8^{\text {th }}$ Habit: From Effectiveness to Greatness. New York: Simon Schuster.

8 Sebagai benchmark studi kasus dapat dibaca Rhodes, J. (2003). Can E- Commerce Enable Marketing in an African Rural Women's Community Based Development Organisation. Science Journal, 6. 
untuk hal yang positif dan bermanfaat luas, terlebih lagi menyambut MEA (Masyarakat Ekonomi ASEAN) tahun 2015.

d. Dengan semakin kompetitifnya produk industri kreatif yang dihasilkan, berefek pada peningakatan omset penjualan, maka akan semakin meningkatkan kesejahteraan masyarakat.

e. Mendorong masyarakat baik sisi penjual maupun pembeli untuk berperilaku bisnis secara etis dan bermoral, karena mengimplementasikan marketing Syariah index. Kebiasaan berbisnis secara etis dan bermoral, diharapkan mendorong lahirnya masyarakat yang bebas dari persoalanpersoalan moral, baik korupsi, penipuan dan lain-lain. ${ }^{9}$

\section{B. Metode Penelitian}

\section{Desain Penelitian}

Penelitian ini merupakan penelitian deskriptif (descriptive research) dengan tindak lanjut pembentukan model syariah marketing index untuk industri kreatif di Sleman yang diintegrasikan dengan kemajuan teknologi informasi berbentuk portal. Penelitian dilakukan terhadap para pelaku industri kreatif dengan berbagai sektor yang ada di wilayah Kabupaten Sleman. Penentuan wilayah penelitian didasarkan pertimbangan teoritis dan teknis serta eksistensi Kabupaten Sleman merupakan salah satu Kabupaten di Wilayah Propinsi DIY dengan jumlah pelaku industri kreatif yang cukup besar.

\section{Metode Pengumpulan data dan Metode Analisis}

Metode pengumpulan data yang digunakan adalah penyebaran kuisioner yang didukung dengan wawancara. Bentuk kuisioner terlampir di bagian lampiran laporan penelitian ini. Dari penngumpulan data yang dilakukan, terkumpullah data yang berupa informasi dan angka. Data berikut penafsirannya disajikan dalam bentuk tabel, grafik, bagan dan gambar. Metode analisis terhadap data dilakukan dengan metode analisis kualitatif.

9 Dampak praktik berekonomi secara Islami bagi pembentukan karakter dapat ditelusuri lebih lanjut dalam artikel yang ditulis Nur Kholis, "Praktik Ekonomi Islam di Indonesia dan Implikasinya bagi Pembangunan Karakter Bangsa", Jurnal AHKAM, Vol. 13, No. 02, diterbitkan STAIN Tulungagung. Perspektif lain, bisa dibaca DePorter dan M. Hernacki, 2000, Quantum Busines, Membiasakan Berbisnis Secara Etis dan Sehat, Terjemahan, Bandung 
Metode penelitian yang dijalankan diharapkan menghasilkan out come yang digambarkan dalam diagram fishbone sebagai berikut:

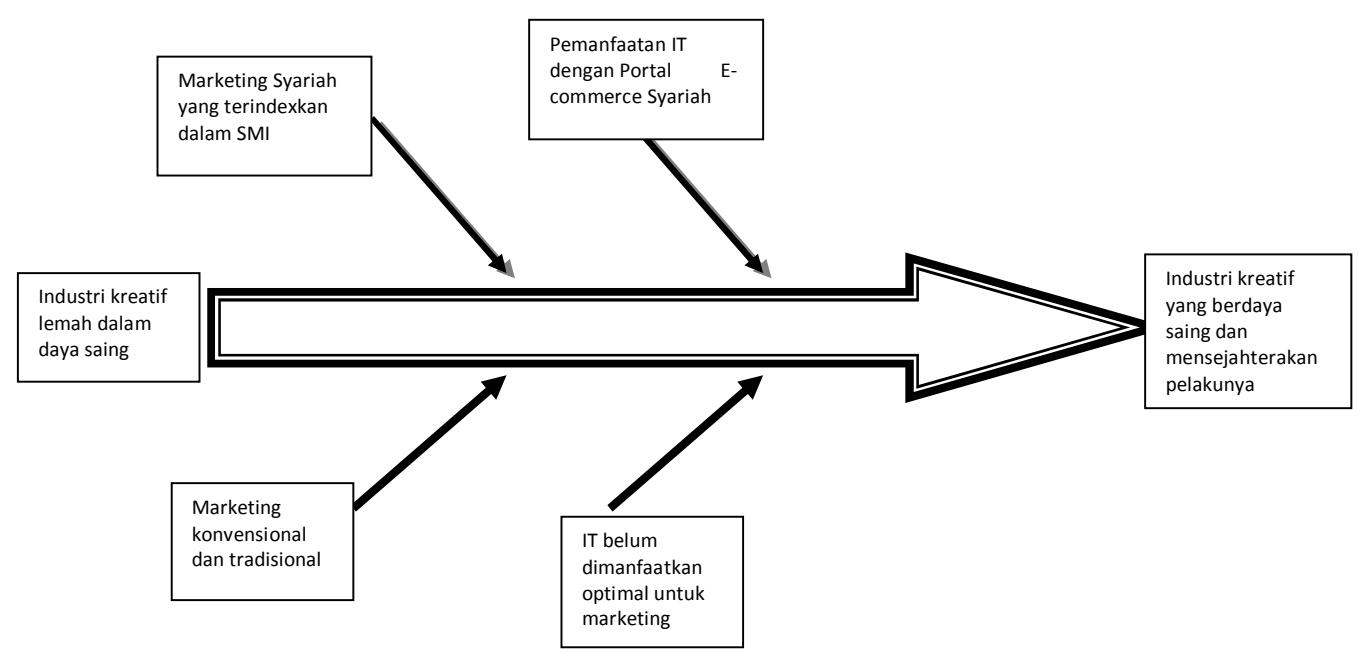

Gambar 1. Fishbone penelitian

Penelitian tahun ke-1 telah menghasilkan temuan sebagai berikut: para responden dalam menjalankan usaha ekonomi kreatif menempatkan modal sendiri menjadi tumpuan utama, diikuti pinjaman perbankan. Di samping itu, didapati bahwa seluruh sampel telah menggunakan komputer dan internet dalam menunjang usahanya terutama untuk keperluan administratif dan komunikasi on line. Namun terdapat beberapa pelaku usaha yang belum familiar media social. Temuan lain, para pelaku ekonomi kreatif masih sangat terbatas dalam penggunaan portal e-commerce untuk pemasaran. Hal ini menjadi sangat strategis bagi pihak-pihak yang mempunyai kepedulian mengembangkan ekonomi kreatif dengan membangun portal e-commerce untuk mendorong kemajuan melalui pemasaran on line. Para responden belum menjadikan pemasaran syariah sebagai keunggulan, apalagi jika dilengkapi dengan Syariah Marketing Index (SMI). Dengan adanya SMI yang melekat dalam marketing yang dilakukan melalui marketing on-line akan meningkatkan trust masyarakat dalam bertransaksi industri kreatif melalui on-line.

Selanjutnya tahapan penelitian pada Tahun II adalah: a). Mengidentifikasi pelaku industri kreatif yang layak dan tepat untuk menjadi mitra pelaksanaan 
program sebagai pilot project. b). Penggalian lebih detail informasi terkait dengan industri mitra agar informasi yang mendukung pemasaran melalui IT dapat dimasukkan dalam portal yang tersedia. c). Pengembangan aplikasi portal dengan sms gateway. d). Menyusun modul aplikatif untuk memahami model Syariah Marketing Index (SMI) dan aplikasinya dalam memasarkan produknya serta benefit yang diperoleh jika menerapkannya bagi pelaku industri kreatif. e). Mengaplikasikan portal e-commerce yang telah terintegrasi dengan SMI dalam suatu model portal e-commerce berbasis nilai Syariah untuk pemasaran produk industri kreatif di Kabupaten Sleman secara riil untuk transaksi komersial yang diharapkan dapat meningkatkan pendapatan dan daya saing industri kreatif yang menjadi mitra. f). Diseminasi melalui seminar nasional dan proseding seminar yang ber-ISBN. g). Publikasi ke jurnal nasional terakreditasi

Road map penelitian mengacu pada road map RIP yang telah disusun DPPM UII. Road map ekonomi kreatif dalam RIP DPPM UII, ${ }^{10}$ sebagai berikut:

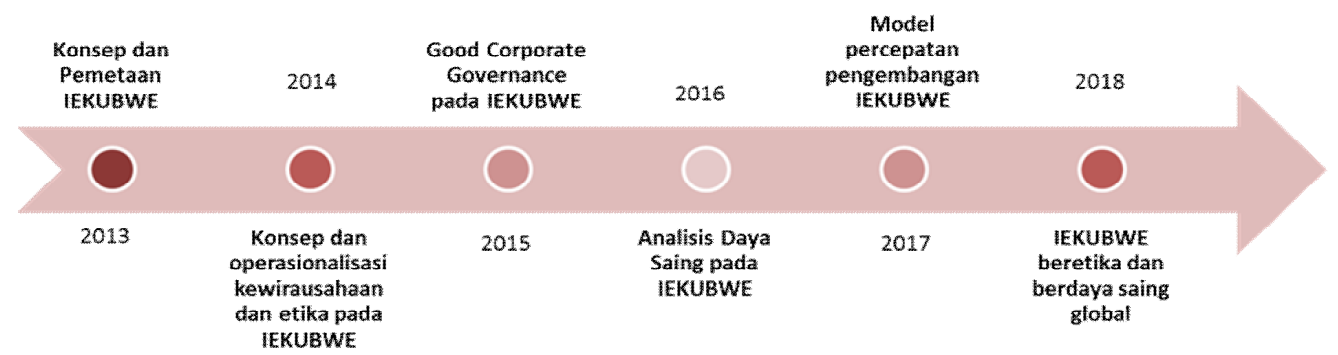

Gambar 2. Road map pengembangan ekonomi kreatif

\section{Tahapan Pelaksanaan Penelitian}

Tahapan penelitian dalam dua tahun tergambar dalam bagan alur sebagai berikut:

\footnotetext{
10 Rencana Induk Penelitian DPPM UII Tahun 2012-2016, diterbitkan oleh DPPM UII.
} 


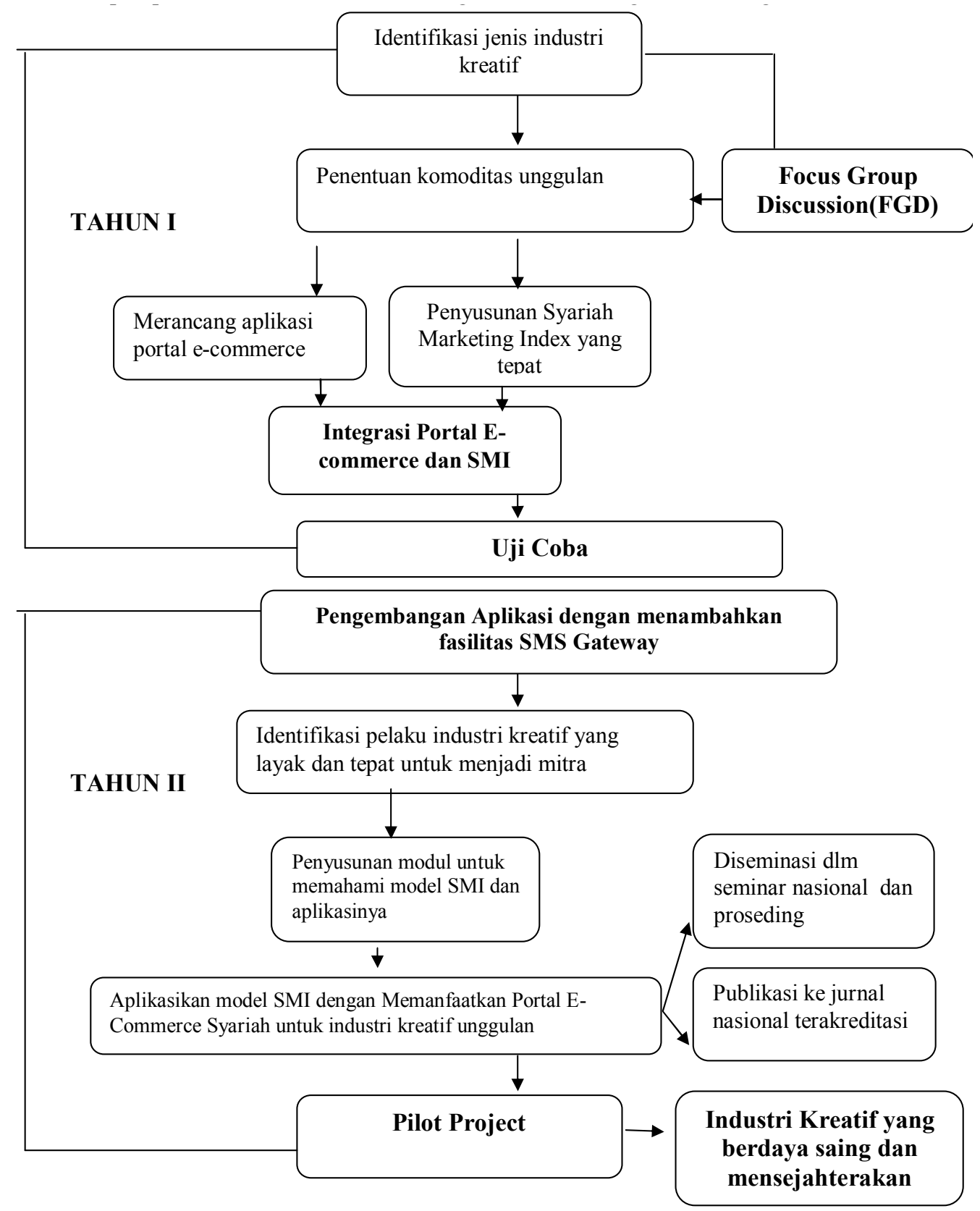

Gambar 3. Bagan Alur Penelitian 


\section{Hasil dan Pembahasan}

\section{Profil Responden}

Penyajian profil responden sebanyak 68 pelaku ekonomi kreatif mencakup identitas responden (usia, pendidikan, jabatan dalam perusahaan), usaha yang digunakan oleh pelaku ekonomi kreatif sebanyak 68 responden tersebut terdiri dari pelaku usaha yang bergerak pada kuliner, periklanan, penerbitan dan percetakan, TV dan radio, film, video dan fotografi, musik, seni pertunjukan, arsitektur, desain, fesyen, kerajinan, pasar barang seni, permainan interaktif, layanan komputer dan piranti lunak, penelitian dan pengembangan.

Nilai Mean (rata-rata) untuk variabel tersebut yang masing-masing merupakan dumi maka nilai mean tidak ada arti statistiknya, karena besaran variabel dumi nilainya hanya merupakan pembeda yang merupakan nilai dari variabel pilah. Namun demikian nilai mean dikaitkan dengan nilai mode dan median variabel-variabel tersebut dapat digunakan untuk mendeteksi tingkat normalitas sebaran distribusi data. Jika nilai besaran rata-rata hitung $=$ median $=$ modus maka akan diperoleh suatu distribusi sebaran data yang simetris dan sebaliknya jika sebaran distribusi data tidak simetris maka nilai: mean $\neq$ median $\neq$ modus. Besaran nilai hitung dipengaruhi oleh nilai ekstrim sementara modus tidak dipengaruhi nilai ekstrim dan median dipengaruhi oleh kedudukannya.

\section{Usia Responden}

Responden yang menjalankan ekonomi kreatif tersebar dari umur yang relatif muda di bawah 30 tahun sampai usia di atas 51 tahun. Secara rinci sebaran distribusi frekuensi usia responden sebanyak 133 pelaku ekonomi kreatif disajikan pada tabel berikut:

Tabel 1.: Profil Responden Pelaku ekonomi kreatif Berdasarkan Umur

\begin{tabular}{|c|c|c|c|}
\hline \multirow{2}{*}{ No. } & \multirow{2}{*}{ Umur (th) } & \multicolumn{2}{|c|}{ Jumlah Responden } \\
\cline { 3 - 4 } & & (Orang) & Persentase (\%) \\
\hline 1 & Lebih kecil 30 & 24 & 35.30 \\
\hline 2 & $31-40$ & 23 & 33.80 \\
\hline 3 & $41-50$ & 15 & 23.10 \\
\hline 4 & Lebih besar 51 & 5 & 7.80 \\
\hline & Jumlah & 68 & 100 \\
\hline
\end{tabular}

Sumber: Data primer diolah 
Dari tabel di atas menunjukkan bahwa dari 68 pelaku ekonomi kreatif, sebagian besar berumur kurang dari 30 tahun yakni 24 orang (35.30\%), kemudian disusul usia 31-40 tahun yakni 23 orang (33.80 \%), 41 - 50 tahun yakni 15 orang $(23.10 \%)$ dan yang terkecil $>51$ tahun sebesar 5 orang $(7.80 \%)$. Banyaknya pelaku ekonomi kreatif yang berumur di bawah 30 tahun menunjukkan adanya kemauan penduduk usia muda untuk menekuni sektor ekonomi kreatif. Seperti tampak pada grafik di atas, bahkan dari setiap rate umur menjadi pelaku ekonomi kreatif. Hal ini menunjukkan bahwa minat masyarakat terhadap ekonomi kreatif sangat besar sehingga perlu dikembangkan lebih besar lagi.

\section{Pemanfaatan Teknologi Informasi}

Dalam hal pemanfaatan teknologi informasi yang dilakukan oleh responden mencakup pemanfaatan komputer, internet, social media, dan portal pemasaran. Keempat komponen tersebut digunakan oleh pelaku ekonomi kreatif untuk berbagai macam pemanfaatan. Distribusi yang dihasilkan oleh empat komponen diatas mempunya distribusi normal dan non simetris. Hal ini terjadi demikian karena pada prakteknya tidak semua data yang mengikuti distribusi normal seperti apa yang ada di teori. Ada juga data yang sedikit menyimpang dari distribusi normal seperti yang ditunjukkan oleh sebagian kurva diatas yang menunjukan pemanfaatan responden dalam hal sistem informasi. Sebuah distribusi dikatakan miring ke kiri atau negatif jika puncak kurva berada di sebelah kanan atau landainya agak memanjang ke arah kiri dan miring ke kanan atau positif jika puncaknya berada disebelah kiri atau landainya agak memanjang ke arah kanan .

Data menunjukkan bahwa pemanfaataan sistem informasi yang dilakukan oleh responden yaitu komputer untuk kegiatan lainnya/desain, internet untuk kegiatan lainya. Untuk sosial media responden kurang memanfatkannya terbukti dan dapat dilihat pada data dan portal pemasaran responden kebanyakan belum menggunakanya. Maka adanya penelitian ini diharapkan responden sadar bahwa penggunaan teknologi informasi dalam kegiatan bisnis sangat dibutuhkan. 


\section{Identifikasi Calon Mitra sebagai Pelaksana Pilot Project}

Banyaknya ragam dan besar kecilnya sektor ekonomi kreatif yang ada menjadi sampel dalam penelitian mempunyai potensi yang sangat besar untuk menerapkan SMI. Sebagai upaya efisiensi dan efektivitas uji coba (pilot project), dilakukan pembatasan melalui penetapan kriteria-kriteria baik secara metodologis maupun praktis. Untuk kriteria metodologis, mencakup: a) Usaha kreatif yang terpilih memenuhi kriteria-kriteria yang ditentukan oleh Syariah Marketing Index (SMI), b) secara ekonomi memiliki prospek usaha yang menguntungkan.

Kriteria praktis mencakup antara lain pemilik usaha menyatakan kesediaan secara sukarela menjadi mitra dan kesesuaian waktu untuk melakukan komunikasi secara intensif, aksesibilitas tempat usaha mudah dijangkau, produk yang dihasilkan secara syar'i halal. Jika produk yang dihasilkan saat ini ada unsur yang tidak halal, ada kesediaan pemilik untuk mengubah produk menjadi halal.

Berbagai sektor ekonomi kreatif yang berpotensi dikembangkan menjadi pilot project adalah mencakup: a) sektor kuliner seperti Dapur Seruni, KCT Kasava, Crispi lele Sari Rasa, AADS (Apa-Apa Ada Disini), SS Adita, Pradana (kripik buah), b) kerajinan seperti Deriji craft, Ardi Craft, Sari Puspa, Prinx Mas, UKM Mekar, c) film, video dan fotografi seperti kencana art fotography, d) Desain interior seperti Desain interior (VLTAVA), e) Percetakan \& Advertising seperti Benny advertising (Non-Islam), f) Fashion seperti Jejo Sport Miranda Rumah Mode.

\section{Model Syariah Marketing Index (SMI) untuk Pemasaran Industri Kreatif}

Model Syariah Marketing Index (SMI) yang dikembangkan mengacu pada koding tertentu. Kode skor penilaian dari kuisioner yang terisi jawaban responden untuk Syariah Marketing Index (SMI), jika menyatakan tidak diberi bobot 0 , sedangkan jika menyatakan ya, diberi bobot 1 . Pembobotan tersebut dipergunakan dalam rangka koding.

Base point SMI yang ditetapkan peneliti adalah $80 \%$. Peneliti tidak menetapkan 100\% dengan pertimbangan, bahwa peneliti belum benar-benar membuktikan perilaku pelaku usaha di lapangan dalam melakukan pemasaran. Nilai yang diperoleh masih berdasarkan selfassessment pelaku usaha dengan metode survey. Dalam konteks pemasaran secara umum, khususnya online, masih ba- 
nyak masyarakat Indonesia yang masih enggan bertransaksi secara online karena belum terlalu percaya kepada pelakunya. Dengan pertimbangan itu, base point-nya ditetapkan $80 \%$. Agar dapat mencapai SMI 100\%, sisanya 20\% diperoleh dari transaksi yang dilakukan. Nah itu juga nantinya akan ada penilaian tersendiri, terutama dari perspektif customer.

Untuk penilaian yang $80 \%$, pembobotannya adalah sebagai berikut:

Tabel 2.: Pertanyaan kuisioner

\begin{tabular}{|c|c|c|c|c|}
\hline No. & Pertanyaan di kuisioner & $\begin{array}{c}\text { Jawaban } \\
\text { ideal SMI }\end{array}$ & $\begin{array}{l}\text { Bobot } \\
\text { Indeks }\end{array}$ & $\begin{array}{l}\text { Kekhususan dalam } \\
\text { Hasil Indeks }\end{array}$ \\
\hline 1. & $\begin{array}{l}\text { Apakah perusahaan anda melakukan usaha } \\
\text { dengan memproduksi, mendistribusikan, dan } \\
\text { memperdagangkan produk yang berbahan } \\
\text { barang yang dilarang Syariah }\end{array}$ & 0 & $8 \%$ & $\begin{array}{l}\text { Jika jawabnya } 1 \text {, maka } \\
\text { SMI-nya langsung } 0 \%\end{array}$ \\
\hline 2. & $\begin{array}{l}\text { Apakah perusahaan anda melakukan usaha } \\
\text { dengan memproduksi, mendistribusikan, dan } \\
\text { menyediakan barang/jasa salah satu atau lebih } \\
\text { unsur berikut: pornografi, perjudian, memabuk- } \\
\text { kan, mendorong perilaku sia-sia, dan lain-lain } \\
\text { yang dikategorikan dapat merusak moral dan } \\
\text { bersifat mudharat }\end{array}$ & 0 & $8 \%$ & $\begin{array}{l}\text { Jika jawabnya } 1 \text {, maka } \\
\text { SMI-nya langsung } 0 \%\end{array}$ \\
\hline 3. & $\begin{array}{l}\text { Apakah perusahaan anda dalam memasarkan } \\
\text { produk melakukan penawaran yang dibuat- } \\
\text { buat, seakan-akan banyak demand terhadap } \\
\text { produk anda, sehingga mendorong calon pem- } \\
\text { beli untuk membeli produk anda? }\end{array}$ & 0 & $8 \%$ & - \\
\hline 4. & $\begin{array}{l}\text { Apakah perusahaan anda dalam memasarkan } \\
\text { produk, anda menampilkan testimoni yang } \\
\text { dibuat-dibuat seakan-akan produk anda sangat } \\
\text { diminati pembeli? }\end{array}$ & 0 & $8 \%$ & - \\
\hline 5. & $\begin{array}{l}\text { Apakah perusahaan anda dalam memasarkan } \\
\text { produk terkadang menjelekkan produk sejenis } \\
\text { kepada konsumen? }\end{array}$ & 0 & $8 \%$ & - \\
\hline 6. & $\begin{array}{l}\text { Apakah perusahaan anda dalam memasarkan } \\
\text { produk melakukan risywah (suap) kepada } \\
\text { pihak yang terkait agar produk anda dibeli? }\end{array}$ & 0 & $8 \%$ & $\begin{array}{l}\text { Jika jawabnya } 1, \text { maka } \\
\text { SMI-nya langsung } 0 \%\end{array}$ \\
\hline 7. & $\begin{array}{l}\text { Apakah perusahaan anda dalam memasarkan } \\
\text { produk berlaku jujur kepada konsumen? }\end{array}$ & 1 & $8 \%$ & - \\
\hline 8. & $\begin{array}{l}\text { Apakah perusahaan anda dalam memasarkan } \\
\text { produk, jika menjanjikan sesuatu kepada kon- } \\
\text { sumen selalu ditepati? }\end{array}$ & 1 & $8 \%$ & - \\
\hline
\end{tabular}




\begin{tabular}{|c|l|c|c|c|}
\hline 9. & $\begin{array}{l}\text { Apakah perusahaan anda menggunakan jasa } \\
\text { lembaga keuangan konvensional, termasuk } \\
\text { perbankan dan asuransi konvensional? }\end{array}$ & 0 & $8 \%$ & $\begin{array}{c}\text { Jika jawabnya 1, } \\
\text { total dana dari lembaga } \\
\text { keuangan konvensional } \\
\text { tidak lebih dari 45\% (se- } \\
\text { suai kriteria DES), maka } \\
\text { bobotnya tetap 8 \%. } \\
\text { Jika jawabnya 1, } \\
\text { total dana dari lembaga } \\
\text { keuangan konvensional } \\
\text { lebih dari 45\%, maka } \\
\text { nilai indeksnya } 0 \% .\end{array}$ \\
\hline 10. & $\begin{array}{l}\text { Apakah perusahaan anda memiliki rasio Kewa- } \\
\text { jiban terhadap Aktiva lebih besar dari 90\%? }\end{array}$ & 0 & $8 \%$ & - \\
\hline & Total & $80 \%$ & $\begin{array}{c}\text { Jika semua jawaban } \\
\text { sesuai ideal SMI, maka } \\
\text { SMI-nya } 80 \%\end{array}$ \\
\hline
\end{tabular}

Sumber: hasil riset diolah.

Hasil pengukuran terhadap hasil survey dengan alat kuisioner terhadap ekonomi kreatif yang ada di wilayah Sleman diukur dengan Syariah Marketing Index (SMI) yang telah disusun sebagaimana di atas, dapat dijelaskan dalam subbab berikut.

\section{Penerapan Marketing Syariah}

Kegiatan pemasaran sebagai ujung tombak pengembangan ekonomi kreatif menjadi sangat strategis untuk dikaji secara mendalam. Dalam penerapan marketing syariah responden diberikan 10 pertanyaan yang mewakili konsep penerapan marketing syariah. Berdasarkan parameter yang diajukan ke responden diperoleh hasil sebagai berikut:

Tabel 3.: Penerapan Marketing Syariah

\begin{tabular}{|l|c|c|}
\hline \multicolumn{1}{|c|}{ Keterangan } & \multicolumn{2}{c|}{ Jumlah } \\
\cline { 2 - 4 } & (responden) & $(\%)$ \\
\hline $\begin{array}{l}\text { 1. } \\
\text { Perusahaan memproduksi, mendistribusikan dan memperdagangkan babi, } \\
\text { anjing, bangkai, katak dll (dilarang Syariah Islam) }\end{array}$ & 0 & \\
\hline $\begin{array}{l}\text { 2. } \\
\text { Perusahaan memproduksi, mendistribusikan dan menyediakan barang por- } \\
\text { nografi, perjudian, memabukkan dll (dilarang Syariah Islam) }\end{array}$ & 0 & 0 \\
\hline $\begin{array}{l}\text { 3. } \\
\text { Dalam memasarkan produk Perusahaan melakukan penawaran yang dibuat- } \\
\text { buat, seakan banyak permintaan terhadap produk perusahaan }\end{array}$ & 2 & 1,18 \\
\hline \begin{tabular}{l} 
4. $\begin{array}{l}\text { Dalam memasarkan produk Perusahaan menampilkan testimoni yang yang } \\
\text { dibuat-buat, seakan produk perusahaan diminati }\end{array}$ \\
\hline
\end{tabular} & 3 & 1,76 \\
\hline
\end{tabular}




\begin{tabular}{|l|r|r|}
\hline $\begin{array}{l}\text { 5. Dalam memasarkan produk, Perusahaan terkadang menjelekkan produk lain/ } \\
\text { sejenis }\end{array}$ & 1 & 0,59 \\
\hline 6. Dalam memasarkan produk, Perusahaan melakukan suap (risywah) & 3 & 1,76 \\
\hline 7. Perusahaan dalam memasarkan produk berlaku jujur kepada konsumen & 64 & 37,65 \\
\hline 8. Perusahaan dalam memasarkan produk, jika menjanjikan selalu ditepati & 62 & 36,47 \\
\hline $\begin{array}{l}\text { 9. Perusahaan menggunakan jasa lembaga keuangan konvensional, termasuk } \\
\text { perbankan dan asuransi konvensional }\end{array}$ & 30 & 17,65 \\
\hline 10. Perusahaan memiliki rasio kewajiban terhadap aktiva lebih besar dari $90 \%$ & 5 & 2,94 \\
\hline
\end{tabular}

Sumber: Data primer diolah

Berdasarkan tabel di atas menunjukkan bahwa secara umum responden sudah menerapkan pemasaran syariah. Hal ini diindikasikan rata-rata responden menyatakan dalam menjalankan usaha ekonomi kreatif tidak mengandung unsur yang haram. Dengan kondidi ini maka pengembangan ekonomi kreatif melalui implementasi aplikasi pemasaran syariah dapat dijadikan modal dasar terbentuknya pengembangan bisnis secara syariah.

Berbagai paparan ekonomi kreatif atas dasar pengamatan sampel dapat dijadikan data awal formulasi kebijakan pengembangan ekonomi kreatif di Kabupaten Sleman. Salah satu komponen yang tidak kalah pentingnya dalam mengembangkan ekonomi kreatif adalah adalah terbentuknya komitmen untuk mewujudkan masyarakat yang sadar Hak Kekayaan Intelektual. Untuk itu diperlukan sosialisasi dan fasilitasi dan serta kemudahan dalam mewujudkan permohonan Hak Kekayaan Intelektual (HK). Bentuk fasilitasi dapat diwujudkan dalam bentuk stimulan biaya untuk pengurusan HKI. Kegiatan ini menjadi sangat strategis mengingat pengembangan eknomi kreatif secara nasional telah ditetapkan dan dipetakan empat daerah untuk menjadi sasaran pemerintah dalam program pengembangan ekonomi kreatif sekaligus menjadi sampel pengembangan sektor tersebut bagi daerah lainnya di Tanah Air. Daerah-daerah tersebut DIY, Solo, Pekalongan dan Bandung.

Melalui penegakan HKI maka kreatifitas masyarakat dapat dikembangkan. HKI menjadi kebutuhan bagi masyarakat. Terlebih dengan semakin berkembangnya teknologi informasi dan komunikasi, menjadikan sekat-sekat teritorial suatu bangsa bahkan daerah menjadi semakin kabur. Suatu kreatifitas yang dihasilkan, sangat mudah diakses bahkan ditiru oleh masyarakat lain. Dalam upaya melindungi karya kreatifitas maka harus ada kepedulian dengan Hak Kekayaan Intelektual. 
Upaya penegakan HKI selaras dengan upaya mendukung program nasional yakni mensukseskan kebijkan ekonomi kreatif yang tertuang dalam Inpres No. 6 tahun 2009. Untuk menciptakan daya kreasi dan daya cipta individu yang bernilai ekonomis dan berpengaruh pada kesejahteraan masyarakat dengan sasaran, arah, dan strategi yang telah ditetapkan. Apabila di masing-masing pemerintah kabupaten dan kota mmampu mengembangkan ekonomi kreatif maka keberadaan ekonomi kreatif menjadi agenda dan dasar bagi suatu daerah membangun ekonominya. Investment of human capital dan creative business menjadi program dan kebijakan dalam menciptakan pertumbuhan ekonomi. Hal tersebut dapat merubah paradigma pembangunan ekonomi global yang menganut prinsip bahwa kekayaan alam merupakan kunci bagi pembangunan dan pertumbuhan ekonomi suatu bangsa untuk bersaing dalam pembangunan global. Terbukti saat ini, negara-negara dengan sumber kekayaan alam yang sangat minim seperti Singapura, Swiss, Filandia dan beberapa negara lainnya mampu menjadi macan ekonomi dunia.

\section{Aplikasi Portal $e$-commerce Industri Kreatif yang sesuai dengan model SMI Index Marketing Syariah}

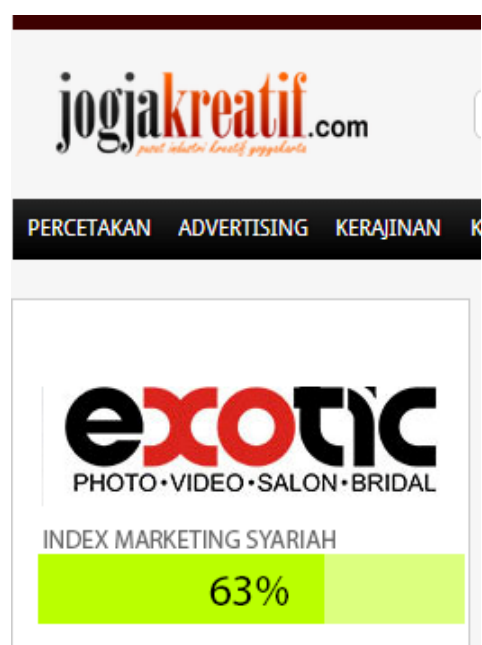

Gambar 4. Tampilan Index marketing Syariah

Index marketing Syariah berdasar kuesioner yang diisikan sebelumnya. Kisaran untuk index marketing Syariah ini adalah 0 - 80\%. Pengunjung bisa melihat 
index marketing Syariah dengan menekan profil dari toko yang tersedia, disitu nanti akan dimunculkan nilai dari index marketing Syariah.

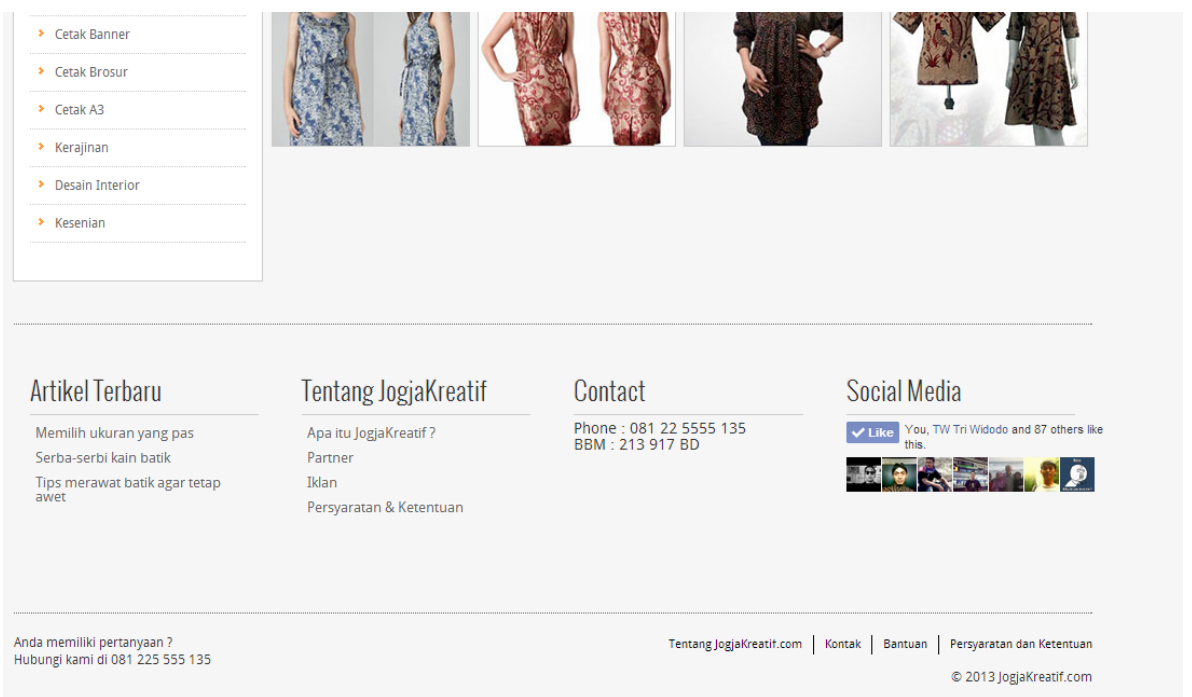

Gambar 5. Tampilan menu technical support

Selain itu juga Jogjakreatif.com memiliki technical support yang akan membantu pembeli dan penjual yang bisa dihubungi melalui nomor hand phone yang ada, social media (facebook, twitter), dan juga instant messaging (YM, BBM).

\section{Pengembangan Aplikasi Portal dengan SMS Gateway}

Pada penelitian tahun ke-1 telah menghasilkan sebuah portal e-commerce (http://jogjakreatif.com) yang memungkinkan pelaku usaha industri kreatif di Kabupaten Sleman untuk memasarkan dan melakukan transaksi dengan pelanggan. Pada aplikasi portal e-commerce yang ada saat itu, telah tersedia fasilitas pemberian informasi bagi pelaku usaha yang terdaftar jika ada transaksi yang masuk melalui email. Melalui fasilitas ini, pelaku usaha tidak diharuskan untuk senantiasa memeriksa secara rutin aktivitas transaksi yang terjadi. Mereka cukup menunggu informasi mengenai transaksi yang terbaru melalui email.

Meski demikian, ternyata tidak semua pelaku usaha industri kreatif yang ada memiliki koneksi internet yang senantiasa online. Kondisi ini dapat me- 
nimbulkan masalah yakni potensi hilangnya transaksi yang terjadi jika pelaku usaha lambat dalam merespon transaksi yang terjadi dikarenakan kelambatan informasi tersebut.

Oleh karena itu guna memberikan alternatif jalur komunikasi lain bagi pelaku usaha, maka pada portal e-commerce ditambahkan fitur SMS gateway. Pemilihan media ini dirasa sesuai dan tepat dengan kondisi saat ini di mana hampir semua orang memiliki handphone meskipun hanya dengan fitur standar yakni voice dan SMS. Diharapkan dengan adanya fitur tambahan ini, pelaku usaha yang tidak memiliki koneksi internet tetap dapat terupdate dengan informasi mengenai transaksi yang terjadi melalui portal e-commerce.

Selain digunakan untuk memberikan informasi bagi pelaku usaha mengenai transaksi yang terjadi, fitur SMS gateway ini juga digunakan sebagai media informasi dan komunikasi guna mendekatkan pelanggan dengan portal e-commerce ini. Beberapa hal yang dapat dilakukan dengan SMS gateway ini adalah:

1. mengirimkan beragam informasi mengenai produk-produk terbaru maupun promo terbaru yang dipasang oleh pelaku usaha.

2. mengirimkan kata-kata hikmah guna memotivasi pelanggan sehingga kedekatan hubungan dengan pelanggan tidak hanya dimotivasi oleh alasan bisnis semata, akan tetapi juga dengan tujuan menyebarkan kebaikan bagi pelanggan.

Pada penelitian ini, peneliti telah menentukan untuk menggunakan suatu sistem bernama kalkun ${ }^{11}$ yang merupakan sebuah sistem SMS gateway berbasis Gammu. Gammu sendiri merupakan sistem yang dapat digunakan mengontrol fitur-fitur telepon seperti SMS, panggilan, daftar kontak dan lainnya untuk dapat diintegrasikan dengan sistem aplikasi yang kita miliki. Selanjutnya sistem ini akan diintegrasikan dengan aplikasi portal e-commerce agar dapat mengirimkan SMS secara otomatis kepada pelaku usaha jika terjadi suatu transaksi dan juga secara berkala mengirimkan informasi-informasi penting bagi pelanggan.

Berikut adalah beberapa tampilan aplikasi bernama kalkun yang digunakan dalam pengembangan aplikasi portal dengan SMS Gateway. Pada gambar 1 ditunjukkan tampilan dashboard dari SMS gateway. Pada halaman ini ditampil-

11 http://kalkun.sourceforge.net/ 
kan statistik terkait SMS yang masuk/ keluar dan sebagainya. Tampilan halaman muka Jogjakreatif.com berikut menu pemililhan produk dapat ditunjukkan pada Gambar 6.

Mekanisme transaksi melalui portal yang telah dilengkapi dengan sms gateway adalah sebagai berikut:

\section{Memilih Kategori Produk dan Produsen}

Untuk melakukan pembelian, calon pembeli dapat memilih kategori pada menu di atas, kemudian memilih produsen seperti yang ditunjukkan pada gambar 6 .

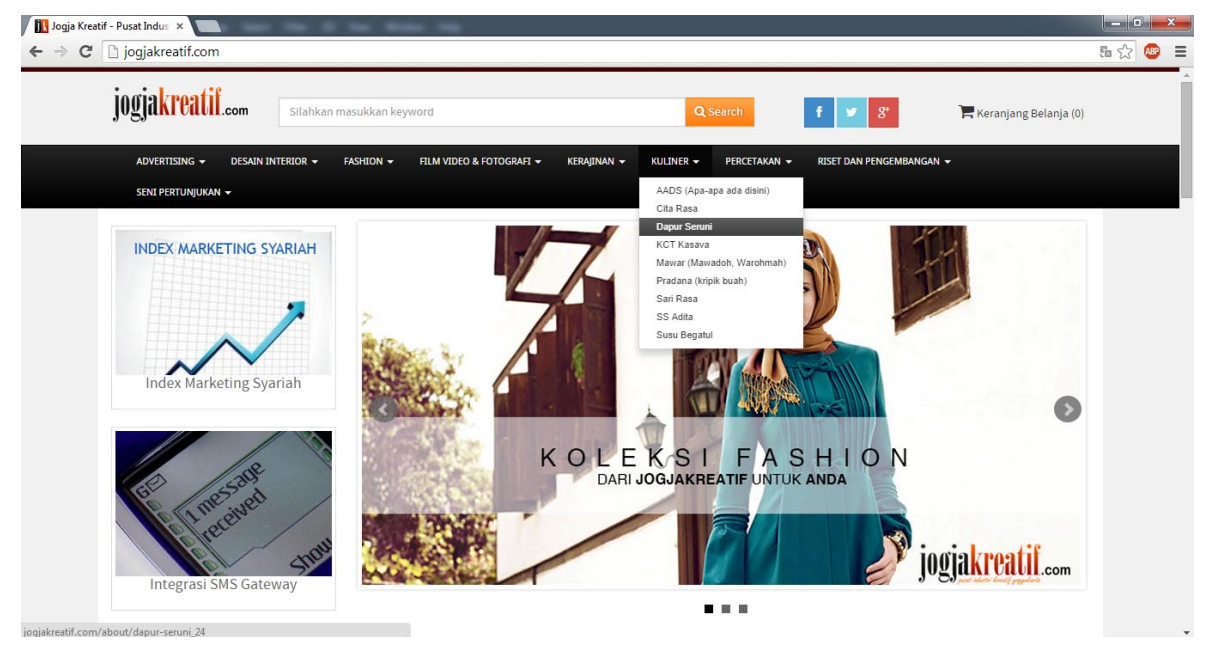

Gambar 6. Halaman Depan dan Pemilihan Menu Kategori Produk

\section{Tampilan Halaman Produsen dan Daftar Produk}

Pada gambar 7 terlihat informasi mengenai produsen/penjual dari produkproduk yang ditawarkan di Jogjakreatif.com. Terdapat informasi mengenai alamat, nomor telepon, dan juga email. Di bawahnya ditampilkan produkproduk yang dijual oleh produsen. Selanjutnya untuk melakukan transaksi pengguna dapat langsung menekan tombol "Beli". Meski demikian, jika calon pembeli ingin melihat terlebih dulu informasi mengenai produk atau layanan yang ditawarkan, maka dapat melihat informasi detil produk tersebut sebagaimana ditunjukkan pada Gambar 7. 


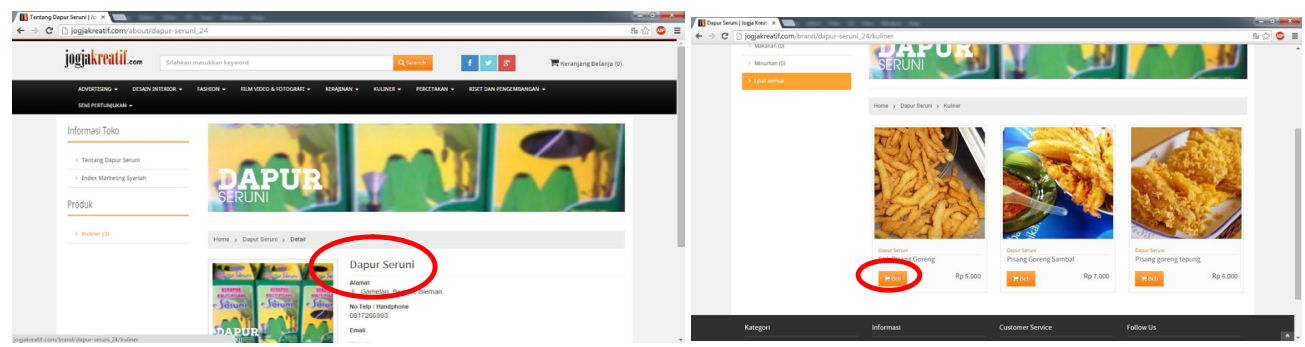

Gambar 7. Tampilan halaman produsen dan daftar produk

\section{Rekapitulasi Transaksi}

Setelah calon pembeli memilih produk dan jumlah yang akan dibeli, maka produk-produk apa saja yang akan dibeli masuk ke keranjang belanja sebagaimana ditunjukkan pada Gambar 8. Jika calon pembeli masih ingin melakukan pemilihan dan pembelanjaan produk lainnya, dapat memilih tombol "Continue Shopping" atau tombol "Checkout" untuk mengakhiri proses transaksi.

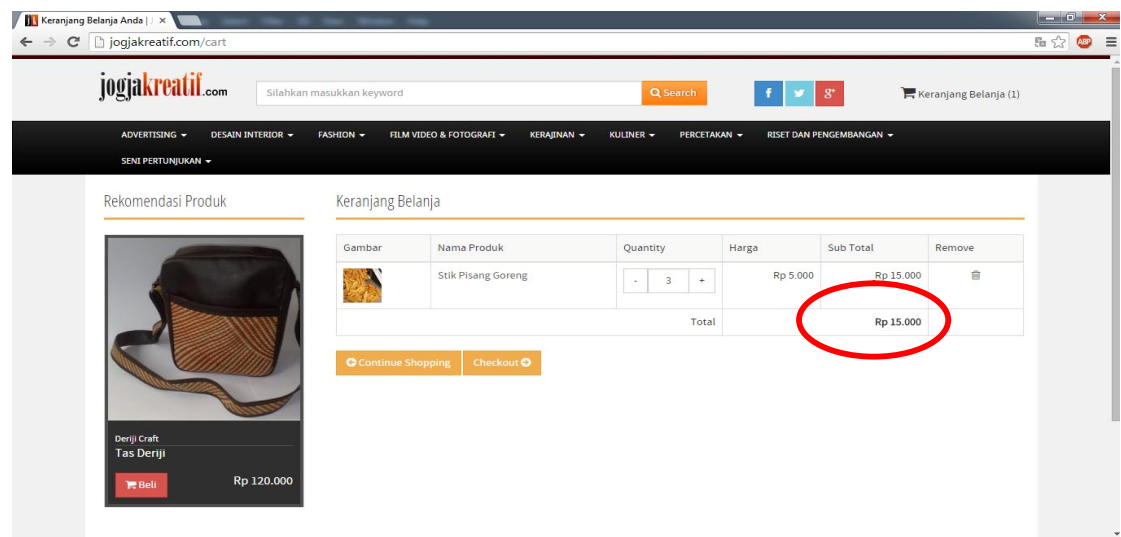

Gambar 8. Halaman Keranjang Belanja

\section{Detail Informasi Pembeli}

Proses selanjutnya adalah pengisian informasi pembeli. Pembeli dapat mengisikan nama lengkap, email, no telepon, dan juga alamat sebagaimana ditunjukkan pada Gambar 9. Hal ini untuk memudahkan produsen untuk berkomunikasi dan bertransaksi kepada pembeli 


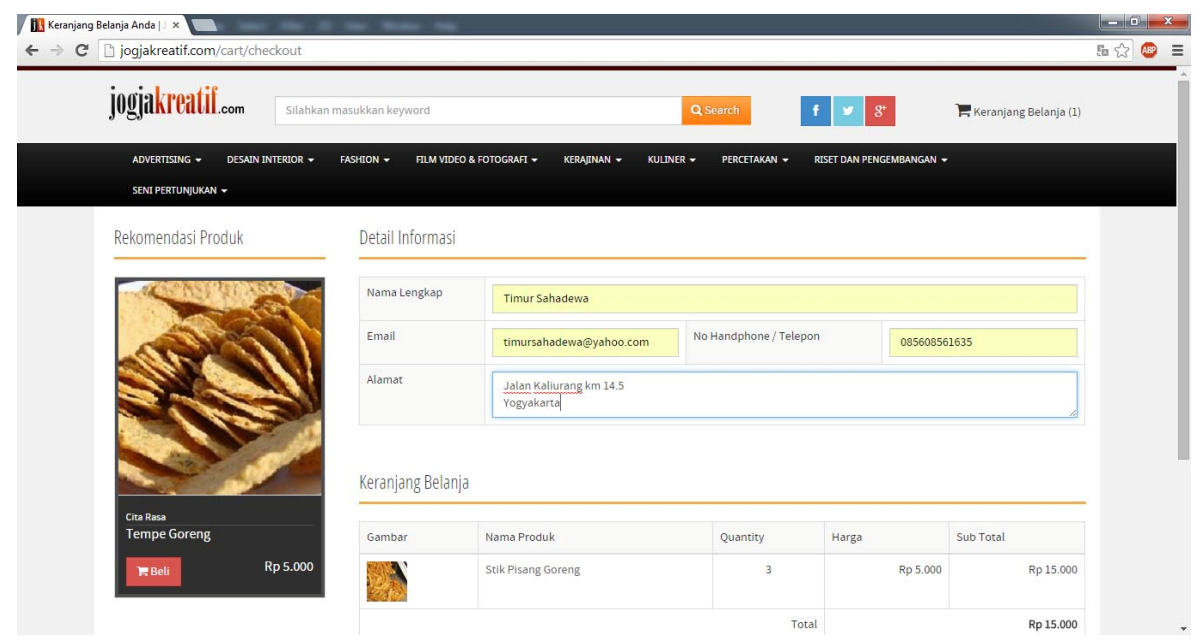

Gambar 9. Halaman Pengisian Informasi Pembeli

\section{Konfirmasi Pembelian}

Selanjutnya untuk mengakhiri transaksi, pembeli dapat menekan tombol “Konfirmasi Pembelian" sebagaimana ditunjukkan pada Gambar 10.

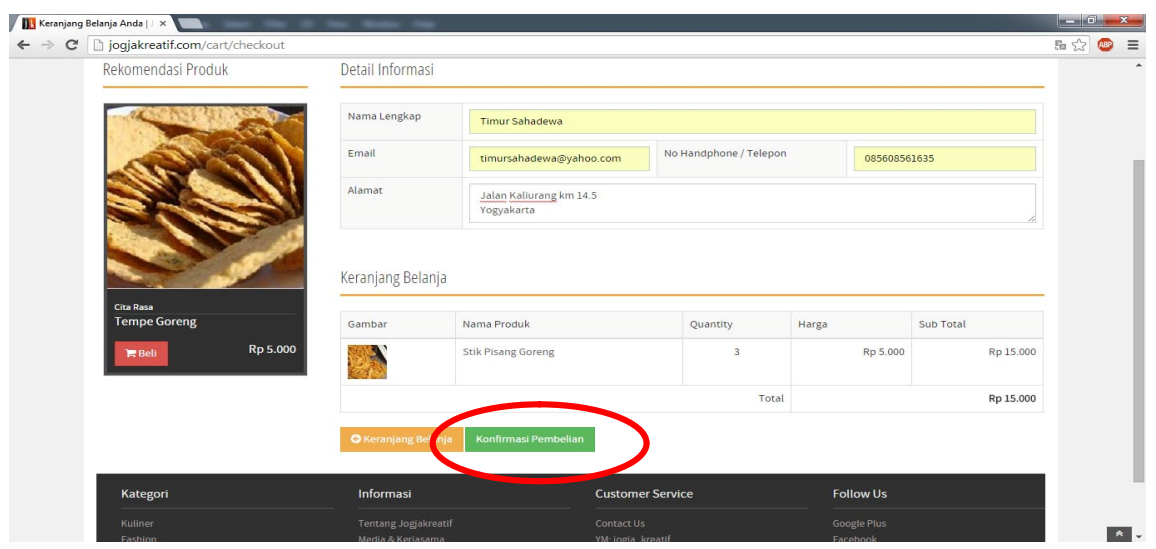

Gambar 10. Halaman Konfirmasi Pembelian

\section{Laporan Sukses}

Setelah itu, pembeli akan diarahkan menuju halaman informasi yang menyatakan bahwa transaksi yang dilakukan telah sukses sebagaimana ditunjukkan pada Gambar 11. Pada saat yang bersamaan, sistem mengirimkan notifikasi melalui SMS kepada produsen/penjual mengenai pemesanan yang baru dilakukan pembeli. Notifikasi melalui SMS seperti ini dimak- 
sudkan untuk mempercepat respon dari penjual atas pesanan yang ada. Pada Gambar 10 ditunjukkan notifikasi SMS yang dikirimkan memuat informasi mengenai produk dan jumlah yang dipesan serta data pemesan yang meliputi nama, alamat, email dan nomor telepon pemesan. ${ }^{12}$

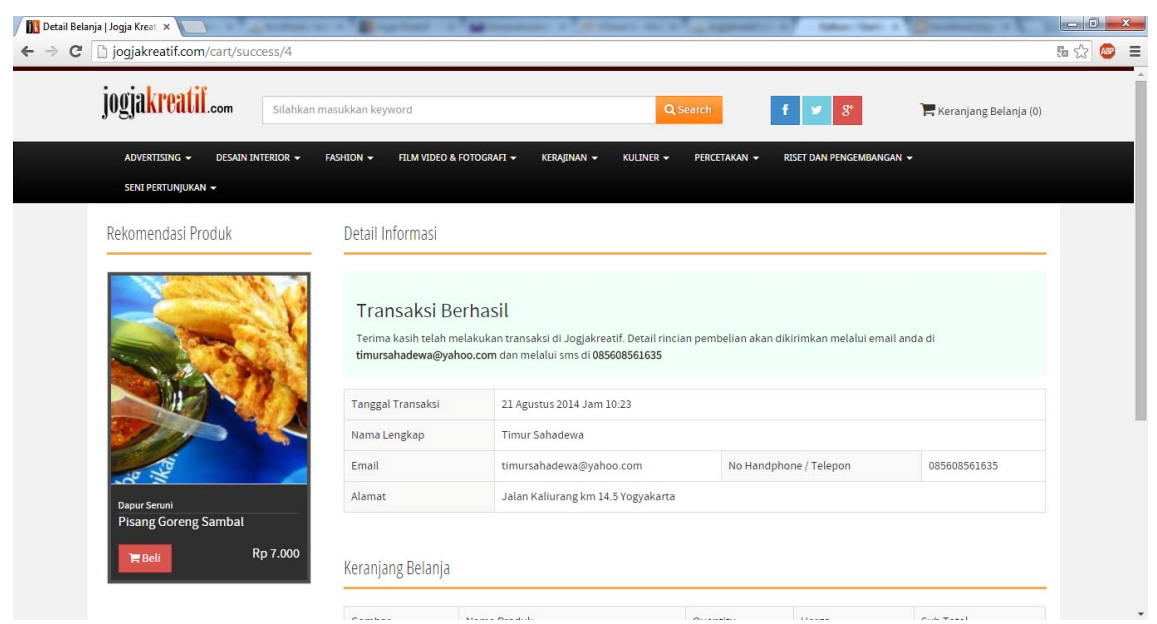

Gambar 11. Halaman informasi bagi pembeli bahwa transaksi yang dilakukan sukses

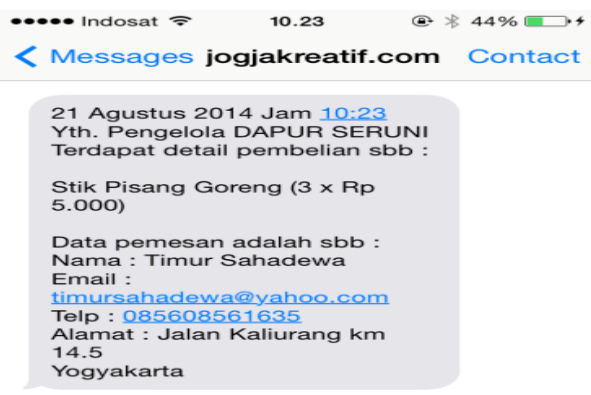

[0] Text Message Send

Gambar 12. Notifikasi SMS bagi penjual

${ }^{12}$ Untuk info lebih detail dan peluang mempraktikkannya, silahkan mengunjungi http:/ /jogjakreatif.com 


\section{Kesimpulan}

Berdasarkan pembahasan yang dipaparkan, berkaitan permasalahan utama bagaimana model penguatan kapasitas pemasaran produk industri kreatif yang menggunakan prinsip pemasaran syariah dengan memanfaatkan portal E-Commerce dalam rangka meningkatkan pendapatan dan daya saing produk industri kreatif di Kabupaten Sleman diperoleh simpulan sebagai berikut:

1. Seluruh sampel telah menggunakan perangkat computer dan internet dalam menunjang usahanya terutama untuk keperluan administratif dan komunikasi secara on line. Namun demikian untuk penggunaan media social selain internet terdapat beberapa pelaku ekonomi kreatif yang belum terlalu familiar. Untuk itu dalam riset tahun ke-2 didalami calon mitra yang paling potensial untuk menjadi pilot project.

2. Para pelaku ekonomi kreatif masih sangat terbatas yang menggunakan portal e-commerce untuk meningkatkan pemasaran. Hal ini menjadi sangat stratagis bagi pihak-pihak yang mempunyai kepedulian mengembangkan ekonomi kreatif dengan membangun portal e commerce untuk mendorong kemajuan ekonomi kreatif melalui pemasaran on line. Integrasi triple helix, yang mencakup dunia kampus, pengusaha dan pemerintah menjadi sangat strategis untuk mengisi celah yang belum mampu terisi oleh para kalangan pelaku ekonomi kreatif.

3. Secara umum para responden dalam menjalankan usaha ekonomi kreatif tidak mengandung unsur yang haram. Dengan kondisi ini maka pengembangan ekonomi kreatif melalui implementasi aplikasi pemasaran syariah dapat dijadikan modal dasar terbentuknya pengembangan bisnis secara syariah. Untuk itu perlu dilengkapi dengan indeks yang kemudian dinamakan dengan Syariah Marketing Index (SMI). Dengan adanya SMI yang melekat dalam marketing yang dilakukan melalui marketing on-line akan meningkatkan trust masyarakat dalam bertransaksi industri kreatif melalui on-line.

4. Pada penelitian ini telah dihasilkan sebuah portal e-commerce (http://jogjakreatif.com) dan telah dilengkapi dengan sms gateway yang memungkinkan pelaku usaha industri kreatif di Kabupaten Sleman untuk memasarkan dan melakukan transaksi dengan pelanggan secara on line. Melalui fasilitas ini, pelaku usaha tidak diharuskan untuk senantiasa memeriksa secara 
rutin aktivitas transaksi yang terjadi. Mereka cukup menunggu informasi mengenai transaksi yang terbaru melalui email. Meski demikian, ternyata tidak semua pelaku usaha industri kreatif yang ada memiliki koneksi internet yang senantiasa online. Kondisi ini dapat menimbulkan masalah yakni potensi hilangnya transaksi yang terjadi jika pelaku usaha lambat dalam merespon transaksi yang terjadi dikarenakan kelambatan informasi tersebut. Oleh karena itu guna memberikan alternatif jalur komunikasi lain bagi pelaku usaha, maka pada portal e-commerce ini kami tambahkan fitur SMS gateway. Pemilihan media ini dirasa sesuai dan tepat dengan kondisi saat ini di mana hampir semua orang memiliki handphone meskipun hanya dengan fitur standar yakni voice dan SMS. Diharapkan dengan adanya fitur tambahan ini, pelaku usaha yang tidak memiliki koneksi internet tetap dapat terupdate dengan informasi mengenai transaksi yang terjadi melalui portal e-commerce.

\section{E. Ucapan Terimakasih}

Peneliti menyampaikan terima kasih yang sebesar-besarnya kepada Kopertis Wilayah V D.I. Yogyakarta dan DP2M DIKTI Kemendikbud RI atas programnya dengan menyediakan berbagai skema penelitian, salah satunya hibah bersaing. Alhamdulillah kami diberi amanah untuk menjalankan riset dengan skema hibah bersaing. Terima kasih proposal penelitian kami disetujui untuk didanai dalam durasi waktu 2 tahun. Program-program riset DP2M DIKTI Kemendibud RI sangat visioner dalam rangka membawa kemajuan bagi bangsa Indonesia. Ucapan terima kasih yang tak terhingga juga peneliti sampaikan kepada semua pimpinan Universitas Islam Indonesia, terutama pimpinan berikut jajaran staf di DPPM UII, yang telah dengan sangat baik memfasilitasi semua proses riset yang kami lakukan. Semoga semua kebaikan yang diberikan diberikan balasan yang lebih baik dari Allah Swt. Ucapan terima kasih yang tak terhingga juga peneliti sampaikan kepada semua pelaku industri kreatif yang telah bersedia mengisi kuisioner dan bersedia diwawancara, serta sebagiannya didalami seluk beluk bisnisnya untuk diproyeksikan menjadi mitra pilot project, semoga bisnisnya sukses dan barakah, terutama setelah menerapkan Syariah marketing. 


\section{DAFTAR PUSTAKA}

Afzalurrahman, 1997, Muhammad Sebagai Seorang Pedagang, Jakarta: Yayasan Swarma Bhuny

Andam, Z. R. (2003). e-Commerce and e-Business (pp. 1-47). Kuala Lumpur.

DePorter dan M. Hernacki, 2000, Quantum Busines, Membiasakan Berbisnis Secara Etis dan Sehat, Terjemahan, Bandung

Gubernur DIY, 2006 " Pelaksanaan Layanan Kesehatan Bagi Masyarakat Miskin Di DIY dalam Seminar Nasional Pelayanan Kesehatan Keluarga Miskin (Gakin) Antara Harapan dan Kenyataan dalam http:/ / www. pemda-diy.go.id/berita/article.php?op=Print\&sid=2337 diakses pada tanggal 16 Agustus 2007

Hermawan Kertajaya \& M. Syakir Sula (2006), Syariah Marketing. Bandung: Mizan dan MarkPlus\&Co

Hermawan Kertajaya (2002), MarkPlus On Strategy. Jakarta: PT Gramedia Pustaka Utama.

Heru dkk, 2007, Total Manajemen Berbasis Al-Fatihah, Inspirasi Indonesia Sukses, Solo: M Frontline Promosindo.

Lai, S.-ling. (2010). Social Commerce - E-Commerce in Social Media Context. World Academy of Science, Engineering and Technology 722010 (pp. 3944).

Muhammad Ismail Yusanto dan M. K. Widjajakususma, 2001, Menggagas Bisnis Islami, Jakarta: Gema Insani Press

Nur Kholis, "Praktik Ekonomi Islam di Indonesia dan Implikasinya bagi Pembangunan Karakter Bangsa", Jurnal AHKAM, Vol. 13, No. 02, diterbitkan STAIN Tulungagung.

OECD. (2004). ICT, E-BUSINESS AND SMEs. Paris.

Philip Kotler (1997), Marketing Management, $9^{\text {th }}$ edition. Prentice Hall Publishing Priyadi, Unggul (2011) Penyusunan Master Plan Pengembangan Ekonomi Kreatif di Propinsi DIY Tahun 2011, Didanai BAPPEDA DIY

Rhodes, J. (2003). Can E- Commerce Enable Marketing in an African Rural Women's Community Based Development Organisation. Science Journal, 6 .

Stephen R. Covey (2004), The $8^{\text {th }}$ Habit: From Effectiveness to Greatness. New York: Simon Schuster 
TIM PPST-DPPM UII (2007), Studi Potensi Bambu Dusun Brajan, Hasil Penelitian, Yogyakarta, Tidak dipublikasikan

UN-ESCWA. (2010). Social Media, e-Commerce and NGOs.

Wahid, F., \& Iswari, L. (2007). Adopsi Teknologi Informasi Oleh Usaha Kecil dan Mengengah di Indonesia. Seminar Nasional Aplikasi Teknologi Informasi (SNATI) 2007 (Vol. 2007, pp. 75-79). 
92 Millah Vol. XIV, No. 1, Agustus 2014 